\title{
ANAESTHETIC MANAGEMENT FOR CORONARY ARTERY BYPASS SURGERY
}

\author{
EMERSON A. MOFFITT
}

OPEN-HEART SURGERY with whole body perfusion is close to its 25 th birthday. ${ }^{1-3}$. Although anaesthesia for these patients has steadily evolved and improved over this period, it is only in the last several years that there have been significant advances in the understanding of patients with coronary artery disease and, hence, in their anaesthetic management. This progress has been due to the realization that patients with compromised coronary blood supply react differently and so must be managed differently than those with congenital or valvular lesions. ${ }^{4}$

Patients with coronary disease can be divided into low-risk and high-risk categories in reference to anaesthesia and surgery.

Low-risk patients have adequate left ventricular function. They have not had myocardial infarctions and have no dyskinetic areas. They have normal cardiac output. Their primary symptom is angina. They have a left ventricular end-diastolic pressure of less than $12 \mathrm{~mm} \mathrm{Hg}$ and an ejection fraction over 0.5 .

High-risk patients have poor left ventricular function. They have had previous myocardial infarctions with residual dyskinetic areas. Cardiac output is subnormal and there is often evidence of failure. Left ventricular end-diastolic pressure is more than $15 \mathrm{~mm} \mathrm{Hg}$ and the ejection fraction is less than 0.3 to 0.5 .

\section{Pre-operative Management}

The anaesthetist estimates the anaesthetic risk on the basis of four criteria. These are (1) the state of the circulatory system; (2) the state of the respiratory system; (3) state of the blood, and (4) medication. The following questions must be asked.

(1) Circulatory system. Is the patient in the low risk or the high risk group? Has there been heart

This subject was presented on Dec. 10, 1977, at the I5th Bernard H. Eliasberg Memorial Symposium: "Topics on the Management of a Patient with Coronary Artery Disease" sponsored by the Department of Anesthesiology, Mount Sinai School of Medicine, New York, N.Y.

E.A. Moffit, M.D. F.R.C.P.(C), Professor and Head, Department of Anaesthesia. Dalhousie University and Victoria General Hospital, Halifax. N.S. failure or myocardial infarction? Is there hypertension or arrhythmia? Has he (she) diabetes mellitus or obesity?

(2) Respiratory system. Is there dyspnoea or hypoxaemia? Has the patient been a smoker? is pulmonary function abnormal?

(3) Blood. Are the haematocrit, clotting factors, electrolytes and enzymes abnormal?

(4) Drugs taken. Is the patient taking or has he taken digitalis, diuretics, propranolol, antihypertensive or antiarthythmic drugs?

The greater the number of affirmative answers to these questions, the higher the anaesthetic and operative risk.

In general, cardiac patients are more subject than normal patients to the following problems ${ }^{5}$ during operation:

(a) enlarged blood volume may lead to fluid and electrolyte problems;

(b) a greater incidence of thromboemboli (e.g. . pulmonary);

(c) a greater incidence of respiratory infection (e.g. pneumonia);

(d) hepatic and renal dysfunction leading to altered effects of drugs.

The cumulative effect of these factors, added to the stress of operation, may precipitate congestive heart failure.

Acute heart failure during operation may be precipitated, then, by fear and apprehension, pre-operative pain, or induction of anaesthesia (with myocardial depression and vasodilatation). Other factors may be a greater risk of fluid overload or reduced ability to handle even the usual amounts of fluid administered during operation and post-operative fluid rentention. The crucial problem is the inability of these patients to increase. cardiac output to meet the greater metabolic demands of the operative period.

\section{PREMEDICATION}

Patients requiring coronary vein grafts are more anxious than other "cardiac" patients. One should take liberal time for verbal reassurance. attempting to relax them by explanation of the approaching major crisis in their lives. This must be supplemented by heavy pharmacological se- 
dation. Many combination of drugs can be used. One highly useful sequence is pentobarbitone $100 \mathrm{mg}$ the night before operation, followed by oral diazepam 5-10 mg two hours before and morphine 5-15 mg one hour before operation. Morphine is both suitable and effective for cardiac patients.

\section{Concepts of Preserving Cardiac Function in the Presence of Coronary Disease}

With multiple narrowing or occlusion of coronary arteries, oxygen supply is decreased to areas of the myocardium. For survival a balance must be maintained between myocardial oxygen supply and oxygen demand. ${ }^{6}$

Oxygen supply is governed basically by the rate of coronary flow and determinants of oxygen delivery; that is, saturation of haemoglobin and the haematocrit.

Myocardial oxygen demand is governed by the heart rate, the state of contractility, preload (end-diastolic ventricular volume and pressure) and afterload (mainly arterial pressure). All conditions which increase these factors increase myocardial oxygen consumption and, in the presence of a reduced or fixed supply, can produce ischaemia. Common among these factors are tachycardia, hypertension and increased positive inotropic agents in the blood, either endogenous or exogenous.

In the medical management of ischaemia, reduced demand is matched to the reduced supply of oxygen by propranolol and vasodilators such as nitroglycerine.

In the anaesthetic management of these patients, we must supply as much oxygen as possible by increasing inspired oxygen concentration, by maintaining ventilation and arterial pressure, and by avoiding severe haemodilution. Oxygen consumption must be contained by avoiding tachycardia, hypertension and hypervolaemia. Elevation of endogenous or exogenous catecholamines must be avoided if possible. Myocardial contractility and blood pressure should be reduced slightly below pre-operative levels to decrease myocardial oxygen consumption.

\section{CirCulatory EFFEcts of ANAESTHETIC Drugs}

Drugs producing general anaesthesia decrease myocardial contractility and arteriolar and venous tone in direct proportion to their concentration in blood' (Table I). One exception is
TABLE I

Circulatory Effects of anaesthetic Drugs

\begin{tabular}{ll}
\hline halothane, enflurane & $\begin{array}{l}\text { contractility } \downarrow \\
\text { vasodilatation } \\
\text { rate } \downarrow \\
\text { danger of low } \mathrm{Pa}_{\mathrm{O}_{2}} \\
\text { contractility } \downarrow \\
\text { nitrous oxide }\end{array}$ \\
contractility $\downarrow$ \\
vasodilatation \\
vasodilatation \\
morphine, fentanyl & $\begin{array}{l}\text { cardiac ouput } \uparrow \\
\text { rate } \uparrow \\
\text { little efiect } \\
\text { ketamine }\end{array}$ \\
diazepam & rate $\uparrow$ \\
pancuronium, gallamine & rate $\downarrow$ \\
succinylcholine & prolonged by lidocaine, \\
tubocurare & quinidine \\
\hline
\end{tabular}

TABLE II

ANAESTHETIC TEChNique

\begin{tabular}{ll}
\hline Induction: & $\begin{array}{l}\text { thiopentone } \\
\text { diazepam } \\
\text { morphine }\end{array}$ \\
Pre-intubation: & $\begin{array}{l}3-5 \mathrm{mg} / \mathrm{kg} \\
\text { halothane or enflurane } \\
\text { in oxygen } \\
\text { pancuronium } \\
\text { lidocaine spray }\end{array}$ \\
Maintenance: & $\begin{array}{l}\text { nitrous oxide-oxygen } 50: 50.1 \mathrm{mg} / \mathrm{kg} \\
\text { notent agent of choice } \\
\text { normocarbia } \\
\text { controlled ventilation }\end{array}$ \\
\hline
\end{tabular}

ketamine, which increases cardiac output and heart rate. Of the relaxants, pancuronium increases heart rate, while succinylcholine slows it. The effect of tubocurare is prolonged by lidocaine and quinidine.

\section{TECHNiques of ANAESTHESIA}

Anaesthetic drugs and techniques are chosen to fulfill the criteria previously discussed; that is, to produce amnesia and analgesia, to maintain circulation of blood but to control and even to decrease myocardial oxygen demand (Table II).

The well-premedicated patient is anaesthetized by intravenous agents administered in judicious increments. Both thiopentone and morphine can cause hypotension on induction from vasodilatation.

Before tracheal intubation is undertaken a potent inhalation agent, or more morphine, must be given to eliminate the hypertension and 
TABLE III

Drugs for Cardiac ANaesthesia

\begin{tabular}{ll}
\hline & \multicolumn{1}{c}{$\mathrm{mg} / \mathrm{ml}^{*}$} \\
\hline 1. Atropine & 0.1 \\
2. Calcium chloride & 100 \\
3. Phenylephrine & $0.5-1$ \\
4. Ephedrine & 10 \\
5. Digoxin & 0.25 \\
6. Chlorpromazine & 5 \\
7. Sodium bicarbonate & $50 \mathrm{mmol} / \mathrm{amp}$ \\
8. Potassium chloride & $2 \mathrm{mmol} / \mathrm{ml}$ \\
9. Lidocaine & 20 \\
10. Propranolol & $0.5-1 \mathrm{mg}$ dose \\
\hline
\end{tabular}

*Usual concentration for intravenous administration.

TABLE IV

Cardiac Drugs By Intravenous INFUSION

\begin{tabular}{llc}
\hline & \multicolumn{2}{c}{$\mathrm{mg} / 500 \mathrm{ml} \mu \mathrm{g} / \mathrm{mI}^{*}$} \\
\hline 1. & Dopamine & $200=400$ \\
2. & Isoproterenol & $1=2$ \\
3. & Epinephrine & $4=8$ \\
4. & Phenylephrine & $50=100$ \\
5. & Nitroglycerine & $16=32$ \\
6. & Nitroprusside & $50=100$ \\
\hline
\end{tabular}

*Usual concentration of solution for intravenous infusion.

tachycardia which otherwise will result from this manceuvre.

Important factors in the maintenace of anaesthesia are increased arterial oxygen tension, normocarbia to avoid hypokalaemia and control of myocardial oxygen consumption. Patients having coronary bypass grafts have a high incidence of hypertension upon sternotomy and in the post-perfusion and early postoperative periods. This must be controlled by potent anaesthetic drugs, chlorpromazine, nitroprusside, ${ }^{8}$ or nitroglycerine 9 by intravenous infusion. The postoperative hypertension is so frequent that it is prudent to undertransfuse after perfusion while yet maintaining an adequate circulation.

Anaesthetists use a variety of drugs to alter circulation and cardiac performance. Atropine (Table III) blocks vagal bradycardia while small doses of propranolol decrease the heart rate. $\mathrm{Cal}$ cium chloride $\left(\mathrm{CaCl}_{2}\right)$ is a rapidly acting effective positive inotrope, while ephedrine has a milder effect associated with peripheral vasoconstriction. Both potassium chloride $(\mathrm{KCl})$ and lidocaine are effective for ventricular hyper-irritability. Phenylephrine, as a purely peripheral vas-
TABLE V

MONITORING

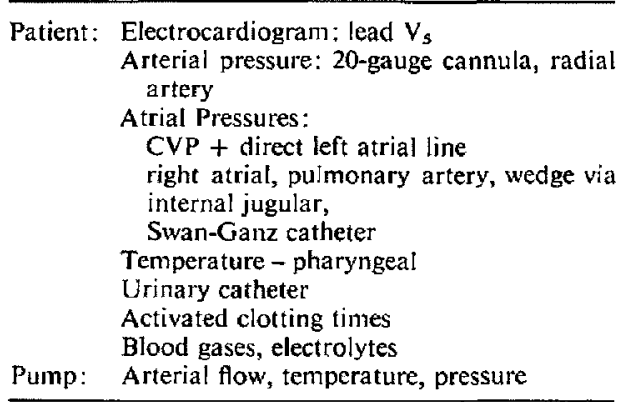

oconstrictor, is useful to manage the hypotension of early perfusion, when coronary flow must be maintained.

Table IV lists drugs such as dopamine, isoproterenol and epinephrine given by intravenous drip to increase contractility. The first choice is dopamine since it causes less increase in myocardial oxygen consumption than the others. Phenylephrine has a pure alpha receptor effect and is indicated to increase arterial pressure if significant vasodilatation is suspected. For patients with coronary disease the more frequent need is to reduce high afterload, especially in the first post-operative hours when pain, shivering and endogenous hormones tend to raise arterial pressure. Nitroprusside and nitroglycerine produce the desired response, but are potentially hazardous drugs. Chlorpromazine gives several hours of blood pressure reduction with less moment-to-moment risk of severe hypotension.

\section{MONITORING}

Because of their narrow margin of cardiac reserve, patients for coronary bypass grafting need careful and extensive monitoring (Table $V$ ). Lead V5 on the electrocardiogram shows ST segment depression more often than other leads. Intraarterial pressure measurement is required. Low risk patients may have right atrial pressure measured throughout, with left atrial pressure available only to assist in managing the return of the patient to his own circulation at the end of perfusion and during the period of rapid transfusion shortly afterwards.

In high-risk patients one requires operative and postoperative knowledge of left-sided filling pressure, either through a flow-directed, pulmonary arterial catheter ${ }^{10}$ or a left atrial line inserted by the surgeon after thoracotomy. In these pa- 
tients with subnormal cardiac output before, and quite possibly low output after operation, ongoing information on left ventricular enddiastolic pressure is essential to successful management of the circulation. Insertion of the Swan-Ganz catheter percutaneously through the right internal jugular vein" has rapidly become widely used by cardiac anaesthetists. Proper placement is achieved by watching the pressure trace; no fluoroscope is needed. This has been one of the most important advances in cardiac anaesthesia since it began about 25 years ago.

\section{Circulatory Problems During Anaesthesia}

Three kinds of untoward events may occur with an incidence in direct relation to the severity of pre-operative cardiac dysfunction. These are problems of heart rate, cardiac rhythm, and ventricular function.

1. Rate problems. Bradycardia of vagal origin occurs frequently. Many of the cardiac drugs (digitalis, propranolol) and anaesthetic drugs (thiopentone, halothane) slow the heart rate. Surgical manipulation within the chest may have the same effect. Hence, atropine is one of the most frequently used drugs.

For tachycardia due to endogenous catecholamines, propranolol in $0.5 \mathrm{mg}$ doses usually slows the rate before a significant negative inotropic effect comes into play.

2. Rhythm problems. Abnormal rhythms, and especially ectopic rhythms, occur regularly. Causes vary from ischaemic areas of myocardium to reduced total body potassium, elevated catecholamines and digitalis toxicity. Treatment depends on the cause. Lidocaine is given to depress ectopic foci. Potassium $2 \mathrm{mmol}$ by intravenous bolus is highly effective when serum potassium is decreased, as it often is from diuresis immediately after perfusion.

3. Decreased ventricular function. Compromised function is the main reason for the operation and quite often the myocardium derives a functional benefit immediately after perfusion in the low-risk patient. In general, however, postperfusion performance depends on the state of pre-operative function.

Also, contractility and cardiac performance from the end of perfusion depends on the success with which the myocardium is protected from hypoxia during grafting. Infusion of solutions containing glucose, insulin, potassium and other agents directly into the coronary circulation before interrupting coronary flow appears to be a major advance in surgical technique. Myocardjal hypothermia, with or without coronary perfusion also adds to the protection.

Whether present preoperatively or supraimposed during operation, some patients have inadequate ventricular function at the end of perfusion. Their management must be discussed next.

\section{Discontinuing Whole Body Perfusion}

When the bypass vein grafts are completed, responsibility for the circulation of blood must be returned to the patient. This involves application of the Frank-Starling law of the heart, ${ }^{12}$ which says that stroke work and cardiac output are directly related to left ventricular end-diastolic volume. This is reflected by left atrial pressure, pulmonary artery wedge pressure or diastolic pressure. It is not adequate to know only right atrial pressure since the relationship of right to left atrial pressure is unpredictable from patient-topatient at that stage.

In brief, to discontinue perfusion, pump flow is reduced sequentially while monitoring some criterion of left ventricular end-diastolic and arterial pressure. ${ }^{13}$ Low pressures are treated by increasing blood volume by arterial transfusion. With adequate ventricular function, satisfactory arterial pressure is maintained with a left ventricular end-diastolic pressure of less than $15-20 \mathrm{~mm} \mathrm{Hg}(1-2.7 \mathrm{kPa})$ and perfusion can be discontinued.

Since overstretching of sarcomeres usually occurs above a left ventricular end-diastolic pressure of about $22 \mathrm{~mm} \mathrm{Hg}(2.9 \mathrm{kPa})$ higher pressures push the heart into lower output, or at least output is not increased. The problem is inadequate contractility, and this requires assistance by positive inotropes.

Among the causes of low output are abnormal rates (e.g. heart block) or rhythms (e.g. atrial fibrillation), severe metabolic acidosis, deep anaesthesia, hyperkalaemia, hypocalcaemia, coronary air embolism, myocardial hypoxic damage and poor pre-existing contractility.

Methods for treatment are listed in Table VI. A further period of perfusion may be needed for reoxygenation and possibly more surgical repair. Calcium choride, up to $1-2 \mathrm{gm}$ in intermittent doses, is the first positive inotropic drug to use. Dopamine is usually the first agent used by drip infusion to stimulate the myocardium. ${ }^{14}$ Any other causes such as acidosis, deep anaesthesia, rhythm and rate abnormalities must be removed. 
TABLE VI

Treatment of Low Cardiac Output

Continued perfusion, for further oxygenation and repair.

Increase blood volume if left atrial or ieft ventricular end-diastolic pressures permit.

Intermittent doses of calcium chloride to $1-2 \mathrm{gm}$.

Catecholamines by infusion: dopamine isoproterenol epinephrine

Vasodilators by infusion: nitroprusside nitroglycerine

Sodium bicarbonate if acidosis is present

Oxygen only, no nitrous oxide

Digoxin, if not fully digitalized

Lidocaine, potassium chloride for ectopic rhythms

Pacing for bradycardia

Establishment of an elevated blood sugar level

Sometimes the combination of positive inotrope and vasodilator drugs together by intravenous infusion will produce a satisfactory circulation. ${ }^{15}$ When all these fail to produce an adequate cardiac output, the circulation must be assisted by intra-aortic balloon pump until the myocardium recovers sufficient power.

\section{Post-operative Care}

The principles of post-operative management are in general similar to those which apply during operation, ${ }^{13}$ and are summarized in the following tabulation:

(a) monitor closely to forestall complications;

(b) maintain optimum blood volume, based on atrial pressure with left atrial pressure of $10-15 \mathrm{~mm} \mathrm{Hg}(1.3-1.9 \mathrm{kPa})$ and right atrial pressure of $5-10 \mathrm{~mm} \mathrm{Hg}(0.65-1.3 \mathrm{kPa})$;

(c) treat low output due to decreased contractility with dopamine, and calcium chloride;

(d) treat hypertension with nitroprusside, nitroglycerine or chlorpromazine to avoid increase in myocardial oxygen consumption.

(e) treat rate and rhythm problems. Ectopic rhythms require lidocaine or potassium chloride, tachycardia responds to propanolol or digitalis, while bradycardia demands atropine or pacing;

$(f)$ keep $\mathrm{Pa}_{\mathrm{O}_{2}}$ above $100 \mathrm{~mm} \mathrm{Hg}(13 \mathrm{kPa})$ and assist ventilation as long as needed.

$(g)$ restrict fluid intake but maintain urinary flow.

(h) give analgesics and sedatives in small doses: opiates and diazepam are recommended.

\section{SUMMARY}

The principles and practice of anaesthesia for patients having coronary bypass grafts are discussed. The essential basic principle is to restrict myocardial oxygen requirement while maintaining oxygen supply. The pathophysiology of coronary artery disease and the pharmacological principles for successful management of the cardiac patient through operation and whole body perfusion for coronary bypass grafts are summarized.

\section{RÉSUMé}

La maladie coronaire et la valvulopathie doivent dicter à l'anesthésiste des lignes de conduite différentes. Les malades à risque peu élevé ont une fonction ventriculaire adéquate, un débit cardiaque, une fraction d'éjection et une pression ventriculaire gauche télédiastolique dans les limites de la normale.

Les malades à risque élevé présentent une fonction ventriculaire médiocre avec débit cardiaque et fraction d'éjection sous la normale et une pression ventriculaire télédiastolique élevée.

Le risque anesthésique doit être évalué d'après les quatre critères suivants:

(1) l'état du système circulatoire.

(2) l'état du système respiratoire,

(3) la condition hématologique,

(4) I'histoire pharmacologique

Plus les perturbations trouvées lors de l'évaluation sont grandes, plus les risques anesthésiques et opératoires sont élevés et on doit toujours craindre que le stress de l'opération ne pousse en insuffisance le cœur dont la compensation est marginale.

Les candidats au pontage coronarien sont inquiets et craintifs; il faut les renseigner sur ce qui va survenir et leur prescrire une prémédication lourde.

Chez ces malades, le transport de l'oxygène au myocarde est diminué alors que le débit coronaire ne peut s'ajuster pour faire face à une demande accrue. En conséquence, il faut essayer de maintenir le travail cardiaque et la consommation d'oxygène à un niveau moindre qu'à l'ètat vigile ou au repos. Toute augmentation du travail cardiaque est à éviter.

Pendant l'anesthésie, on doit garder la $\mathrm{Pa}_{2}$ élevée et la $\mathrm{Pa}_{\mathrm{CO}_{2}}$ dans les limites de la normale tout en évitant une hémodilution excessive. La prévention de la tachycardie, de l'hypertension et de l'hypervolémie nous permettra de garder la consommation én oxygène du cour à un niveau 
favorable, ce qui peut toutefois nécessiter l'emploi de propanolol et de nitroprussiate ou de nitroglycérine par voie parentérale.

Des agents anesthésiques puissants comme l'halothane et l'enflurane sont utilisés pour maintenir une dépression myocardique contrôlée. Les médicaments d'usage courrant comme l'atropine, le chlorure de calcium, la lidocaine, le potassium et la phényléphrine sont utiles lorsqu'on doit modifier le rythme, la fréquence et la contractibilité cardiaque. Pour le pontage coronarien, un monitorage continu de la tension veineuse centrale, de la pression artérielle directe et l'électrocardiogramme sont essentiejs. Le monitorage de la pression télédiastolique ventriculaire gauche exige une canulation directe de l'oreillette gauche ou un cathétérisme de l'artère pulmonaire pour l'obtention de la pression capillaire bloquée. Pour bien contrôler un ventricule gauche à faible contractibilité, il faut connaitre sa pression.

On cessera la perfusion lorsque le volume sanguin sera jugé satisfaisant avec une pression auriculaire gauche ou capillaire pulmonaire moindre que $22 \mathrm{~mm} \mathrm{Hg}(2.9 \mathrm{kPa})$. Une contractilité insuffisante pour maintenir la circulation nécessitera l'administration par la voie veineuse de médicaments à action inotrope comme la dopamine.

Les mêmes principes permettant le contrôle de la circulation, de la ventilation et du volume sanguin à la période anesthésique et opẻratoire, s'appliquent à la période post-opératoire.

\section{REFERENCES}

1. GibBon, J.H. Application of a mechanical heartlung apparatus to cardiac surgery. Minn. Med. 37: $17 I$ (1954)

2. Kirklin, J.W., Donald, D.E., harshbarger, H.G., Hetzel, P.S., Patrick, R.T., \& Swan, H.J.C. Studies in extracorporeal circulation. I. Applicability of Gibbon-type pump oxygenator to human intra-cardiac surgery; 40 cases. Ann. Surg. 144: 2 (1956).
3. PAtrick, R.T., Theye, R.A., \& Moffitt, E.A. Studies in extra-corporeal circulation: $V$. Anesthesia and supportive care during intracardiac surgery with the Gibbon-Lype pump oxygenator. Anesthesiol. 18: 673 (1957).

4. KAPLAN, J.A. The pharmacological treatment of the cardiovascular system. Annual Refresher Course Lectures, American Society of Anesthesiologists 212: 1-11 (1977).

5. GoldBerG, A.H. The patient with heart disease: pre-operative evaluation and preparation. Anesth. Analg. 55: 618 (1976).

6. LAVER, M.B. Coronary artery disease and anesthesia. Annual Refresher Course Lectures, American Society of Anesthesiologists, 2/2: 1-9 Oct (1976).

7. MERIN, R.G. Effects of anesthetic drugs on the heart. Surg. CI. N.A. 55: 759 (1975).

8. Lappas, D.G., Lowenstein, E., Waller, J., FaHMY, N.S., \& DagGetr, W.M. Hemodynamic effects of nitroprusside infusion during coronary artery operation in man. Circulation, Supp. 3, Cardiovascular Surg. 54: $4(1976)$.

9. Flaherty, J.T., ReID, P.R., Kelly, D.T. TAYLOR, D.R., WEISFELDT, M.L., \& PITT, B. Intravenous nitroglycerine in acute myocardial infarction. Circulation $51: 132$ (1975).

10. Swan, h.J.C., Ganz, W. Forrester, J., Marcus, H., Diamond, G., \& Chonette, D. Catheterization of the heart in man with use of a flow-directed balloon-tipped catheter. N. Eng. J. Med. 283: 447 (1970).

11. Civetta, J.M. \& Gabel, J.C. Flow directedpulmonary artery catheterization in surgical patients. Ann. Surg. 176: 753 (1972)

12. Starling, E.H. The Linacre lecture on the law of the heart. London. Longmans, Green and Co. Ltd. (1918).

13. Tarhan, S., White, R.D., \& Moffitt, E.A. Anesthesia and post-operative care for cardiac operations. Ann. Thorac. Surg. 23: 173 (1977).

14. Merin, G., Bitran, D., Uretzky, G., SuperStine, E., Coter, S., \& Borman, J.B. The hemodynamic effects of dopamine foltowing cardiopulmonary bypass. Ann. Thorac. Surg. 23: 361 (1977).

15. LapPas, D.G., Powell, W.M., \& Daggett, W.M. Cardiac dysfunction in the peri-operative period. Anesthesiol. 47: 117(1977). 